\title{
125 years of The Aeronautical Journal
}

This special issue marks the 125th anniversary of the Royal Aeronautical Society's first publication, The Aeronautical Journal. First published in January 1897, the Journal was the brainchild of the then Honorary Secretary of the Society, Captain B F S Baden-Powell, a younger brother of the founder of the Boy Scout movement. Since these early days, the Journal's remit has expanded with the times and, despite the fact that we continue to use the term 'aeronautics', it now includes articles related to flight beyond the boundaries of our atmosphere. In its long history the Journal has thus provided a continuous record of aerospace achievements and its underpinning science and technology. Noteworthy examples are: Wilbur Wright's first technical paper, entitled Angle of Incidence (Vol 5, July 1901) and Frank Whittle's The Turbo-Compressor and the Supercharging of Aero Engines (Vol 35, November 1931, pp 1047-1074). Over the years, the Journal has published articles by many notable figures from the history of aerospace, such as: Ludwig Prandtl, F. W. Lanchester, Sir Frederick Handley Page, Juan Trippe, Igor Sikorsky, Sir Roy Fedden, Theodore von Karman, J. K. Northrop, Glenn Martin, R. T. Jones and Dietrich Küchemann. The Aeronautical Journal remains the oldest aviation journal still in production.

To mark this significant anniversary, we have selected articles and authors that represent some of the breadth of subjects covered by our Journal and also provide a sense of aeronautics in 2022. Given the limited space, this selection is by no means comprehensive or all-inclusive, but I hope that readers will nevertheless, find these articles interesting and thought-provoking. I would like to thank the publications staff at the Royal Aeronautical Society for their help in bringing this issue together and especially all authors for their contributions.

Professor Holger Babinsky FRAeS

Cambridge University Editor-in-Chief

The Aeronautical Journal 